\title{
HUBUNGAN ANTARA LAMA PENGGUNAAN ASPIRIN DENGAN NILAI AGREGASI TROMBOSIT PADA PASIEN HIPERTENSI DI RSUP PROF. DR. R. D. KANDOU MANADO
}

\author{
${ }^{1}$ Devianingsih Andikha Madao \\ ${ }^{2}$ Mongan AE \\ ${ }^{2}$ Manoppo F \\ ${ }^{1}$ Kandidat Skripsi Fakultas Kedokteran Universitas Sam Ratulangi Manado \\ ${ }^{2}$ Bagian Patologi Klinik Fakultas Kedokteran Universitas Sam Ratulangi Manado \\ Email: devimadao@yahoo.com
}

\begin{abstract}
The sufferer of hypertension around the world do not get medical treatment adequately. One of the hypertensive treatments is by the use of anti platelet hypertension aspirin. Aspirin on hypertension is to prevent any clinical manifestation from cardiovascular from happening. However, it could cause arterial wall hardening and decreases haemostasis ability. Test of red blood cell aggregation function is needed to monitor red blood cell function on hypertensive patient. Method: This study was analytical and employed cross sectional research design. The sample of the study were the sufferers of hypertensionfromaspirin usage treated in polyclinic of nephrology - hypertension and heart and cardiac polyclinic of internal diseasedivision in RSUP Prof. Dr. R. D. Kandou Manado. Patients included in inclusion criteria were 40 to 80 years old, proven to have hypertension by doctor, hypertension by aspirin usage, maleand female, and signed in informed consent. Result: There were 20 patients of hypertension by aspirin usage employed as sample in this study. Result of $\mathrm{T}$ test and spearman's correlation test showed that there is no significant correlation between aspirin usage and the number of red blood cells' aggregation (ADP $10 \mu \mathrm{m} p=0,116$, ADP $5 \mu \mathrm{m} p=0,9$ ). Conclusion: On hypertensive patients, there is no correlation between the period of aspirin usage and red blood cells' aggregation.
\end{abstract}

Keywords: hypertension, aspirin, red blood aggregation

\begin{abstract}
Abstrak: Penderita hipertensi di seluruh dunia tidak mendapatkan pengobatan secara adekuat. Salah satu pengobatan hipertensi dengan penggunaan antiplatelet hipertensi aspirin.Aspirin pada hipertensi berguna untuk mencegah terjadinya manifestasi klinis dari kardiovaskular, tetapi dapat menyebabkan terjadi pengerasan dinding arteri dan terjadinya penurunan kemampuan hemostasis.Tes fungsi agregasi trombosit diperlukan untuk memantau fungsi trombosit pada pasien hipertensi. Metode: Penelitian ini bersifat analitik dengan rancang penelitian cross sectional. Sampel penelitian adalah penderita hipertensi dengan penggunaan aspirin yang ada di Poliklinik Nefrologi - Hipertensi dan Poliklinik Jantung dan Pembuluh Darah bagian Ilmu Penyakit Dalam RSUP Prof. Dr. R. D. Kandou Manado. Pasien yang masuk kriteria inklusi yaitu usia 40-80 tahun, terbukti hipertensi oleh dokter, hipertensi dengan penggunaan aspirin, jenis kelamin laki-laki dan perempuan, dan menandatangani informed consent. Hasil: Terdapat 20 pasien hipertensi dengan penggunaan aspirin yang menjadi sampel dalam penelitian ini. Hasil uji $\mathrm{T}$ juga spearman's correlation test didapatkan bahwa tidak terdapat hubungan yang signifikan antara penggunaan aspirin dengan nilai agregasi trombosit (ADP $10 \mu \mathrm{m} p=0,116$, ADP $5 \mu \mathrm{m}$ p = 0,9). Simpulan: Pada pasien Hipertensi, lama penggunaan aspirin dan nilai agregasi trombosit tidak mempunyai hubungan.
\end{abstract}

Kata kunci: Hipertensi, aspirin, agregasi trombosit 
Hipertensi adalah peningkatan tekanan darah yang melebihi tekanan darah normal seperti yang telah disepakati oleh para ahli yaitu lebih dari atau sama dengan 140/90 mmHg (JNC-7) ${ }^{1}$

Menurut WHO dan The International Society of Hypertension (ISH), saat ini terdapat 600 juta penderita hipertensi dan tiga juta diantaranya meninggal setiap tahunnya. ${ }^{2}$ Tujuh dari sepuluh penderita tidak mendapatkan pengobatan secara adekuat. $^{3}$ Di Indonesia masalah hipertensi cenderung meningkat. Hasil Survei Kesehatan Rumah Tangga (SKRT) menunjukkan bahwa penderita hipertensi ada sekitar 27,5\% dan tertinggi didapatkan di Sulawesi Utara $(11,4 \%){ }^{4-6}$

Salah satu pengobatan hipertensi dengan penggunaan antiplatelet aspirin. Keputusan untuk menggunakan aspirin memerlukan pertimbangan rinci risiko dan potensi manfaat terhadap bahaya pengobatan, terutama perdarahan. Aspirin sebaiknya hanya digunakan pada penderita dengan program tindakan gaya hidup termasuk makanan sehat, berhenti merokok, mengontrol tekanan darah dan aktivitas fisik secara teratur. Aspirin pada hipertensi berguna untuk mencegah terjadinya manifestasi klinis dari kardiovaskular, tetapi dapat menyebabkan terjadi pengerasan dinding arteri dan terjadinya penurunan kemampuan hemostasis juga kekakuan pembuluh darah.Secara umum, resiko perdarahan meningkat dengan bertambahnya dosis aspirin.Aspirin adalah obat antiinflamasi (anti radang) non steroid, atau yang lebih dikenal dengan sebutan NSAID (Non Steroidal Anti-inflammatory Drugs) golongan Non-selective COX-1 inhibitor merupakan agonis dari suatu agregasi trombosit. $^{7-9}$

Hipertensi mengakibatkan kerusakan endotel serta kelainan trombosit, biasanya berlangsung lama, salah satu pemeriksaan untuk mengetahui kelainan fungsi trombosit pada hipertensi, digunakan pemeriksaan tes fungsi agregasi trombosit. Agregasi trombosit terjadi sebagai akibat dari perlengketan kompleks antigen-antibody pada membran trombosit mengakibatkan pengeluaran ADP (adenosine diphospat). Hal ini akan menyebabkan trombosit dihancurkan RES (reticulo endothelial system) sehingga terjadi trombositopenia. Agregasi trombosit akan menyebabkan penurunan faktor pembekuan karena pengeluaran faktor III. Agregasi juga mengakibatkan gangguan fungsi trombosit, jadi sekalipun jumlah trombosit masih cukup banyak tapi tidak berfungsi dengan baik. ${ }^{10}$

Dari uraian ini, peneliti ingin mengetahui apakah terdapat hubungan antara lama penggunaan aspirin dengan nilai agregasi trombosit pada pasien hipertensi di RSUP Prof. Dr. R. D. Kandou Manado.

\section{METODE PENELITIAN}

Penelitian ini penelitian analitik dengan pendekatan cross sectional di Poliklinik Nefrologi-Hipertensi dan Poliklinik Jantung dan Pembuluh Darah bagian Penyakit Dalam RSUP Prof. Dr. R. D. Kandou Manado.Pemeriksaan agregasi trombosit di lakukan di Laboratorium Pro-Kita Manado dengan waktu penelitian selama bulan November 2013 sampai Februari 2014. Pemeriksaan agregasi trombosit menggunakan 1 set agregometer Chrono - Log model 490, Chrono - Log recorder model 707, Computer Windows based PC. Sampel penelitian yaitu 20 pasien hipertensi dengan penggunaan aspirin yang termasuk kriteria inklusi. Data dianalisis dengan uji T dan uji Spearman's correlation.

\section{HASIL PENELITIAN}

Subjek penelitian ini berjumlah 20 pasien hipertensi dengan penggunaan aspirin. Usia yang termasuk kriteria inklusi adalah 40-80 tahun. Pada penelitian ini ditemukan usia terendah adalah 40 tahun dan tertinggi 76 tahun (Tabel 1). Pada jenis kelamin ditemukan 14 pasien laki-laki (70 \%) dan 6 pasien perempuan (30 \%) (Tabel 2).

\section{Data nilai trombosit pada pasien hipertensi dengan penggunaan aspirin}

Pada Tabel 3 nilai trombosit terendah adalah $176.000 \mathrm{~mm}^{3}$ dan nilai trombosit 
tertinggi adalah $382.000 \mathrm{~mm}^{3}$. Nilai trombosit $276.000 \mathrm{~mm}^{3}$ mempunyai frekuensi terbanyak yaitu 2 (10\%) dibandingkan yang lain mempunyai frekuensi hanya 1 (5\%). Semua sampel termasuk dalan jumlah trombosit normal.

\section{Nilai agregasi trombosit pasien hipertensi dengan penggunaan aspirin}

Data ADP $5 \mu \mathrm{m}$ pada Gambar 1, kelompok pengguna aspirin $<1$ tahun / 12 bulan dengan hipoagregasi $(<25 \%)$ sebanyak 4 orang dan normoagregasinya (25\%-68\%) sebanyak 9 orang. Sedangkan kelompok pengguna aspirin $>1$ tahun/12 bulan, didapatkan hiperagregasi (>68\%) 1 orang yaitu 83\%, tidak terdapathipoagregasi (<25\%), dan normoagregasi (25\%-68\%) sebanyak 6 orang. Total keseluruhan 1 orang dengan hiperagregasi, 4 orang hipoagregasi, dan sebanyak 15 orang normoagregasi.

Dibandingkan dataADP $10 \mu \mathrm{m}$ yang dapat dilihat pada Gambar 2, sampel yang sama, tidak terdapat hiperagregasi $(>84 \%)$ baik itu kelompok dengan penggunaan aspirin $<1$ tahun/12 bulan maupun $>1$ tahun. Kelompok dengan penggunaan aspirin $<1$ tahun/12 bulan didapatkan orang dengan hipoagregasi $(<49 \%)$ sebanyak 13 , sedangkan penggunaan aspirin $>1$ tahun ada 4 orang dengan hipoagregasi $(<49 \%)$ dan 3 orang normoagregasi (48\%-84\%).Total keseluruhan 17 orang hipoagreasi dan 3 orang lainnya normoagregasi.

\section{Analisis hubungan penggunaan aspirin dan nilai agregasi trombosit}

Pertama-tama dilakukan uji normalitas data untuk melihat apakah data yang terdistribusi normal atau tidak. Uji normalitas data dengan uji $\mathrm{T}$ di dapatkan data tidak normal ADP $10 \mu \mathrm{m}(\mathrm{p}=0,019)$ ADP $5 \mu \mathrm{m}$ $(p=0,006)$ keduanya $p<0,05$. Pada variabel

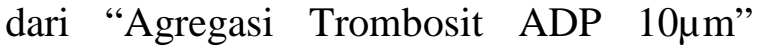
menggunakan Spearman's correlation test dengan hasil $r=-0,563$ dan $p=0,116>0,05$ tidak mempunyai hubungan yang signifikan. Sedangkan pada variabel "Agregasi Trombosit ADP $5 \mu \mathrm{m}$ ” hasil $\mathrm{r}=0,029$ dan $\mathrm{p}$ $=0,9>0,05$ distribusi data ini juga tidak signifikan. Disini peneliti menyertakan juga hasil dari variabel "Lama Penggunaan Obat" dengan hasil $r=0,487$ dan $p=0,029<0,05$. Dengan demikian, disimpulkan bahwa pada penggunaan aspirin dengan ADP $10 \mu m$ dan ADP $5 \mu \mathrm{m}$ tidak terdapat hubungan yang signifikan, sedangkan berdasarkan lama penggunaan obatnya terdapat hubungan yang signifikan tapi kekuatan tingkat hubungan sedang. Oleh karena itu, tidak ditemui hubungan yang signifikan antara lama penggunaan aspirin dengan nilai agregasi trombosit pada pasien hipertensi.

Tabel 1. Karakteristik subjek penelitian berdasarkan usia

\begin{tabular}{ccc}
\hline Usia & Frekuensi (orang) & Persen (\%) \\
\hline$<50$ & 3 & 15 \\
$50-60$ & 3 & 15 \\
$60-70$ & 8 & 40 \\
$>70$ & 6 & 30 \\
Total & 20 & 100 \\
\hline
\end{tabular}

Tabel 2. Karakteristik subjek penelitian berdasarkan jenis kelamin

\begin{tabular}{ccc}
\hline $\begin{array}{c}\text { Jenis } \\
\text { Kelamin }\end{array}$ & $\begin{array}{c}\text { Frekuensi } \\
\text { (orang) }\end{array}$ & $\begin{array}{c}\text { Persen } \\
\text { (\%) }\end{array}$ \\
\hline Laki-laki & 14 & 70 \\
Perempuan & 6 & 30 \\
Total & 20 & 100 \\
\hline
\end{tabular}

Tabel 3. Data nilai jumlah trombosit

\begin{tabular}{ccc}
\hline $\begin{array}{c}\text { Jumlah Trombosit } \\
\left(\mathbf{1 0}^{\mathbf{3}} \mathbf{m m}^{\mathbf{3}}\right)\end{array}$ & $\begin{array}{c}\text { Frekue } \\
\mathbf{n s i}\end{array}$ & $\begin{array}{c}\text { Persen } \\
\mathbf{( \% )}\end{array}$ \\
\hline$<150$ & - & - \\
$150-450$ & 20 & 100 \\
$>450$ & - & - \\
Total & 20 & 100 \\
\hline
\end{tabular}




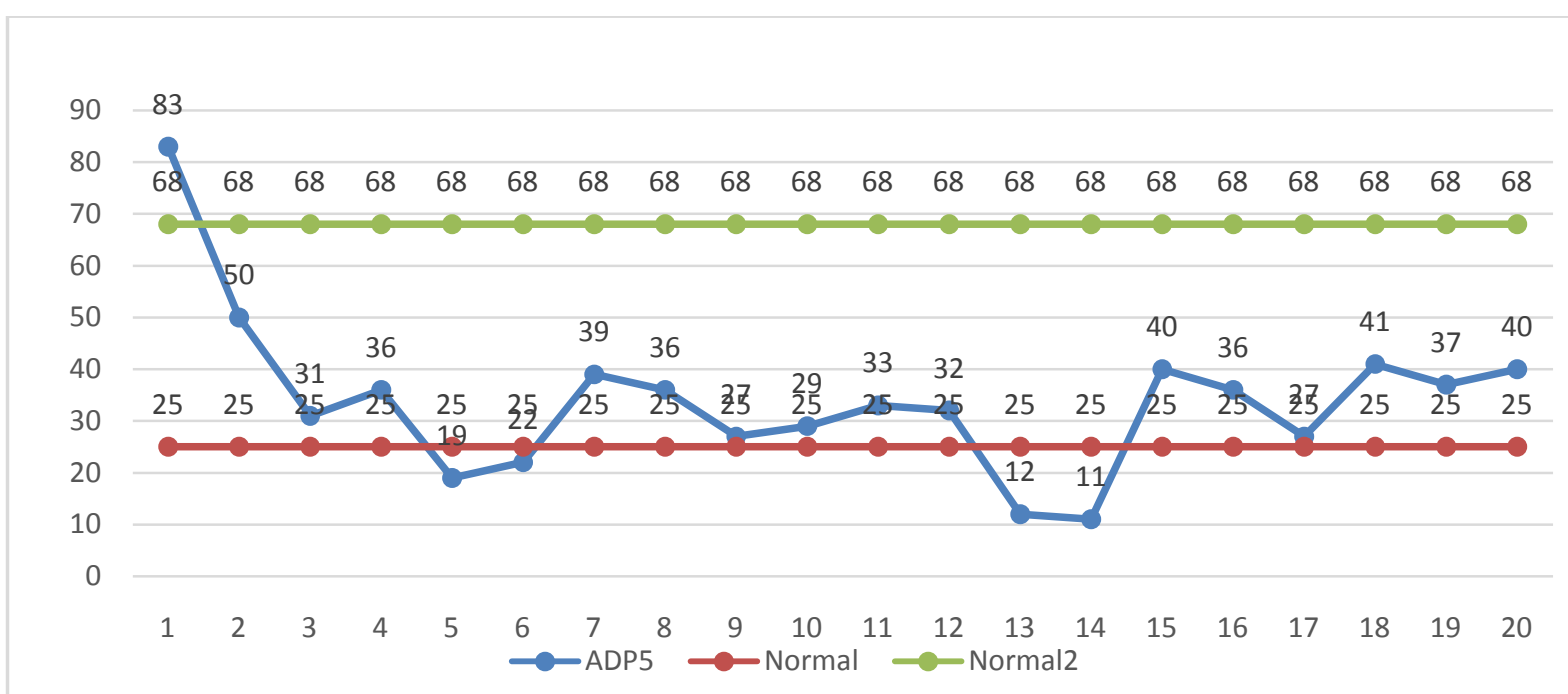

Gambar 1. Nilai agregasi trombosit pada ADP $5 \mu \mathrm{m}$.

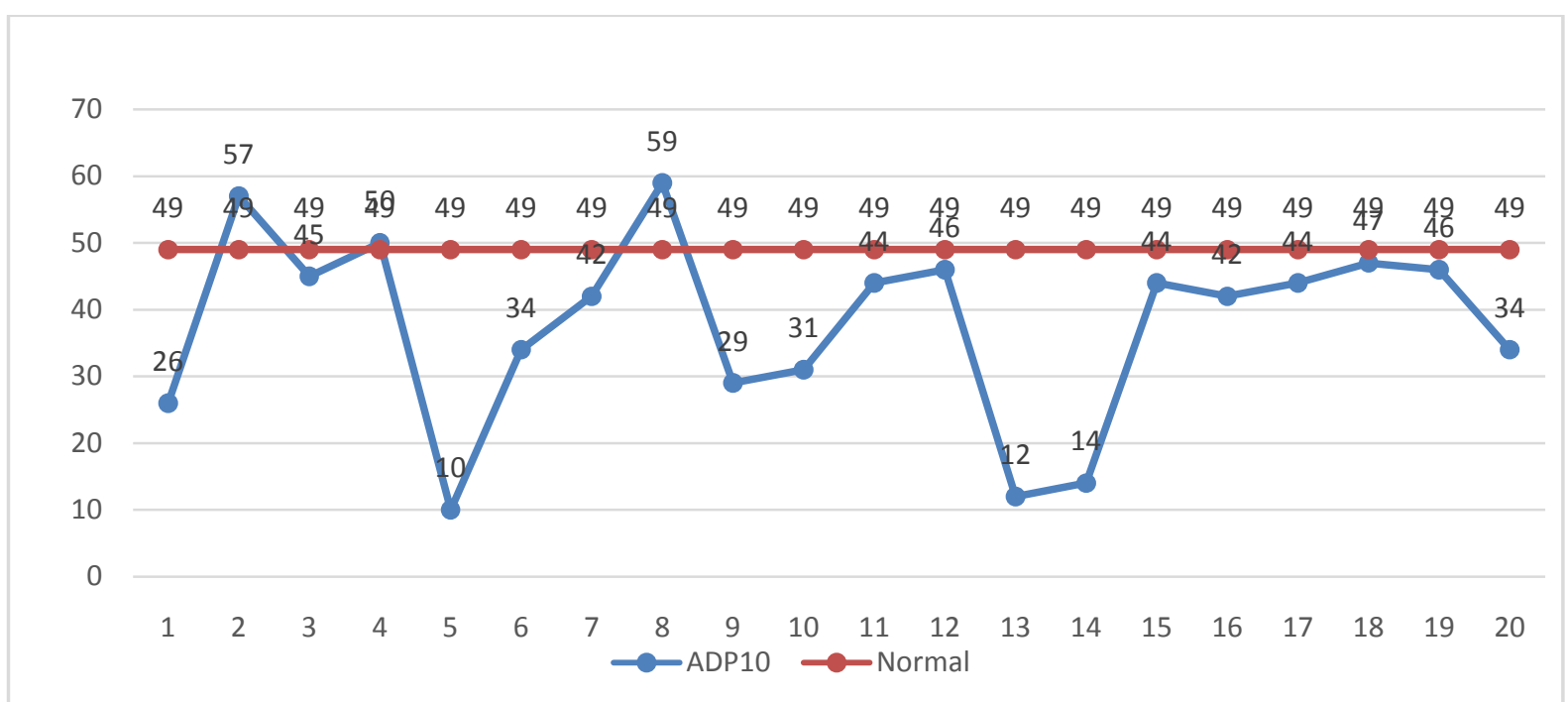

Gambar 2. Nilai agregasi trombosit ADP $10 \mu \mathrm{m}$.

\section{BAHASAN}

Sesuai dengan hasil penelitian secara analitik di Bagian Poliklinik NefrologiHipertensi dan Poliklinik Jantung dan Pembuluh Darah bagian Penyakit Dalam RSUP Prof. Dr. R. D. Kandou Manado, di dapatkan 20 pasien hipertensi dengan penggunaan aspirin dari desember 2013 sampai februari 2014.

Berdasarkan data yang diperoleh, terdapat usia dari 40 - 76 tahun, dengan frekuensi umur terbanyak adalah umur 61 tahun sebanyak 5 orang (25\%). Paling banyak berkunjung adalah pasien laki-laki yaitu 14 orang, sisanya adalah perempuan dan jumlah trombosit semuanya masih dalam batas normal.

Uji normalistik data untuk melihat distribusi data, karena dalam penelitian ini peneliti membandingkan dua data yang dibuat ke numerik yaitu lama penggunaan aspirin dan nilai agregasi trombosit maka peneliti menggunakan Spearman's correlation test.

Para peneliti sebelumnya menemukan dalam sel darah merah terdapat sebuah unsur yang dapat mempengaruhi suatu agregasi trombosit. Unsur tersebut merupakan ADP yang merupakan salah satu agonis untuk meningkatkan agregasi trombosit. ${ }^{11}$ ADP pun tidak berdiri sendiri, dia 
berdampingan dengan kalsium, ATP, dan serotonin yang terkandung dalam granula padat elektron. ${ }^{12}$

Hasil penelitian melalui uji Spearman mendapatkan bahwa tidak ada hubungan yang signifikan antara lama penggunaan aspirin dan nilai agregasi trombosit pada penderita hipertensi di RSUP Prof. Dr. R. D. Kandou Manado. Hasil yang di temukan pada ADP $10 \mu \mathrm{m} \mathrm{p}=0,116>0,05$ sedangkan ADP $5 \mu \mathrm{m} p=0,029>0,05$ juga pada lama penggunaan obat $p=0,029<0,05$. Ini dikarenakan jumlah sampel yang kurang, karena dilihat dari lama penggunaan berhubungan tapi dengan kekuatan tingkat hubungan sedang.

Menurut peneliti hal ini disebabkan berbagai macam faktor yang mempengaruhi baik itu karena penggunaan aspirin maupun fungsi agregasi trombosit itu sendiri, seperti yang diketahui pemberian dosis yang tinggi bisa menyebabkan meningkatnya toksisitas (terutama pendarahan) dan menjadi kurang efektif sebagai antitrombotik. ${ }^{13,14}$ Sebagai hasilnya sesuai dengan teori yang ada, jika kita melihat dari hasil ADP $10 \mu m$ dengan hipoagregasi, memang benar penggunaan aspirin menghambat hiperagregasi. Sehingga tidak terbentuk trombus, membantu mengurangi resiko penyakit kardiovaskular. $^{15,16}$ Tetapi pada ADP5 $\mu \mathrm{m}$ tidak ditemukan secara bermakna mungkin karena obat-obat pendamping lain yang mempengaruhi cara kerja dari aspirin ini. Jika melihat dari intepretasi dari agregasi trombosit, terlihat bahwa efektifitas aspirin berkurang jika penggunaan diatas satu tahun, pembuktian yang sama yang dilakukan Juliani Dewi dan Tinny Endang Hernowati (2008). ${ }^{17}$

Kelemahan dalam penelitian ini diantaranya, jumlah sampel masih kurang dan tidak ada data tekanan darah.Dalam penelitian oleh Govindarajan $\mathrm{dkk}^{18}$ ditemukan hubungan antara aktifasi trombosit dengan tekanan aliran darah. Pada penelitian ini hanya terdapat 2 trace sehingga cukup sulit menginterpretasi hasil pemeriksaan. Hal ini disebabkan pada penelitian ini yang digunakan agregometer model 490 yang hanya memiliki 2 channel (saluran).

Kelebihan penelitian ini sangat membantu mencegah terjadinya komplikasi lebih lanjut dari pasien dengan kelainan pembekuan darah, terutama penderita hipertensi dengan penggunaan aspirin karena telah mengetahui keadaan dari agregasi trombositnya sehingga bisa melakukan tindakan pencegahan.

\section{SIMPULAN}

Berdasarkan hasil penelitian ini dapat disimpulkan bahwa: Menurunnya nilai agregasi trombosit pada pasien hipertensi dengan penggunaan aspirin.Tidak terdapat hubungan antara penggunaan aspirin dengan agregasi trombosit pada pasien hipertensi. Lama penggunaan aspirin mempengaruhi agregasi, terutama penggunaan $<1$ tahun atau 12 bulan.

Sebaiknya untuk peneliti selanjutnya, lebih banyak lagi dalam mendapatkan sampel yang ada untuk mencapai hasil yang maksimal.Disarankan pada saat melakukan penelitian, gunakan juga agonis ADP 1, 2, 5, $10 \mu \mathrm{m}$. Karena hubungan yang tidak signifikan, ada baiknya para pembaca yang tertarik untuk melakukan penelitian selanjutnya meneliti mengenai perbandingan antara lamanya penggunaan aspirin terhadap pasien hipertensi dengan agregasi trombosit. Pemeriksaan agregasi trombosit penting dalam menunjang diagnosis yang berhubungan mengenai pengentalan darah.

\section{DAFTAR PUSTAKA}

1. Nainggolan G. Hiperaldosterone primer. Dalam: Sudoyo AW, dkk, editor. Buku Ajar Ilmu Penyakit Dalam Jilid II. Edisi ke5. Jakarta: Balai Penerbit FKUI; 2009. h. 1094.

2. World Health Organization, International Society of Hypertension Writing Group. 2003 World Health Organization (WHO)/Interational Society of Hypertension (ISH) statement of management of hypertension. Journal of Hypertension.2003; 21(11) : p. 1983-92.

3. Chobanian AV, Bakris GL, Black HR, et al. The Seventh Report of the Joint National 
Committee on Prevention, Detection, Evaluation and Treatment of High Blood Pressure.JAMA. 2003; 289(19): p. 256072.

4. Mansjoer A, dkk, editor. Kapita Selekta Kedokteran Jilid I. Edisi ke-3. Jakarta:Balai Penerbit FKUI; 2000. h. 518-22.

5. Departemen Kesehatan RI Tahun 2006. Profil Kesehatan Indonesia 2004. Jakarta: Bakti Husada; 2006.h. 21-23.

6. Ekowati R, Sulistyowati T. Prevalensi Hipertensi danDeterminannya di Indonesia. Jakarta: Pusat Penelitian Biomedis dan Farmasi Badan Penelitian Kesehatan Departemen Kesehatan RI. 2009; 59(12): h. 580-85.

7. Nwaorgu OGB. Epistaxis: An Overview. Annals of Ibadan Postgraduate Medicine. 2004; 1(2): p. 32-7.

8. Pope LER, Hobbs CGL. Epistaxis: an update on current management. Postgrad Med J. 2005;81: p. 309-14.

9. Josep H. Aspirin for cardiovascular disease prevention. MJA. 2003; 179(3): p. 147152.

10. Setiabudy RD. Patofisiologi Trombosis. Dalam: Setiabudy RD, editor. Hemostasis dan Trombosis. Edisi ke-5. Jakarta: Badan Penerbit FKUI; 2009.h. 34-45.

11. Pulcinelli FM, Pignatelli $P$, Celestini A, et al. Inhibition of Platelet Aggregaion by Aspirin Progressively Decreases in LongTerm Treated Patients. Journal of the American College of Cardiology. 2004; 43: p. 979-84.

12. Hoffbrand AV, Moss PAH. Trombosit, koagulasi darah, dan hemostasis. Dalam: Hoffbrand AV, dkk, editor. Kapita Selekta Hematologi. Edisi ke-6. Jakarta: EGC; 2011. h. 294-298,305-306.
13. Dewoto RH. Antikoagulan, Antitrombotik, Trombolitik dan Hemostatik. Dalam: Gunawan SG, dkk,editor. Farmakologi dan Terapi. Edisi ke-5. Jakarta: FKUI; 2012. h. 813.

14. Wilmana PF, GanS. Analgesik-Antipiretik, Analgesic Anti-inflamasi Nonsteroid, dan Obat Gangguan Sendi Lainnya. Dalam: Gunawan SG, dkk, editor. Farmakologi dan Terapi, edisi ke-5. Jakarta: FKUI; 2012. h. 234,235.

15. Bavry AA, Park K. Aspirin: Its risks, benefits, and optimal use in preventing cardiovascular events.Cleveland Clinic Journal of Medicine. 2013; 80(5): p. 31826. [cited 2013 Oct 22]. Available from: http://www.ccjm. org/content/80/5/318.full.

16. Khan NA, Hemmelgarn $B$, Herman RJ, et al. The 2009 Canadian Hypertension Education Program recommendations for the management of hypertension: Part 2therapy. Canadian Journal of Cardiology. 2009; 25(5): p. 287-98. [cited 2013 Oct 22]. Available from:http://www.ncbi.nlm. nih.gov/pmc/articles/PMC2707169/.

17. Dewi J, Hernowati ET. Hubungan Presentase Agregasi Trombosit dengan Lamanya Konsumsi Aspirin pada Penderita Arteriosklerosisdi Poli Penyakit jantung RSU Dr. Saiful Anwar Malang. Majalah Kedokteran. 2008; 2(3): h. 63-65.

18. Govindarajan V, Udaykumar HS, Chandran KB. Two-Dimensional Simulation of Flow and Platelet Dynamics in the Hinge Region of a Mechanical Heart Valve. Journal Biomech Eng. 2009; 131(3): p. 1-23. Available from: http://www.ncbi.nlm. nih.gov/pmc/articles/PMC2744151/ 